\title{
TRACKING NON-NATIVE SPECIES IN THE ANTARCTIC MARINE BENTHIC ENVIRONMENT
}

http://dx.doi.org/10.4322/apa.2014.082

Andrea de Oliveira Ribeiro Junqueira ${ }^{1, *}$, Ana Carolina Fortes Bastos ${ }^{1}$, Bruna Rachel Rocha ${ }^{1}$

${ }^{1}$ Instituto de Biologia, Universidade Federal do Rio de Janeiro - UFRJ,

Av. Carlos Chagas Filho, 373, CCS, bloco A, sala 089, Ilha do Fundão, Rio de Janeiro,RJ, Brazil

*e-mail: ajunq@biologia.ufri.br

\begin{abstract}
Antarctica is not as isolated as once thought. Although persistent and invasive species have not been detected in the marine environment, some transient species have been. In the present study we investigate the biogeographical patterns of 529 benthic species of 5 target phyla recorded in the Admiralty Bay considering that it is an important tool for the identification of species origin. Most species of Admiralty Bay of the studied phyla are endemic to Sub Antarctica and Antarctica. The second highest percentage was of species with continuous distribution. Chordata and Annelida presented the highest number of disjoint species. However most disjoint species predominate in Antarctica and Sub Antarctica indicating their origin in the Southern Ocean. Cosmopolitan patterns appear to be correlated to taxonomic misidentification or to the occurrence of cryptic species that are being revealed by molecular studies. Only a few disjoint species deserve further investigation.
\end{abstract}

Keywords: bioinvasion, biogeographical patterns, endemism

\section{Introduction}

Bioinvasion means the movement of species into an area beyond their natural range, as a result of human activity. In Antarctica this includes movement of species between biogeographic zones. The main barrier to introductions of non indigenous species (NIS) in the Southern Ocean is the physical dissimilarity between donor and recipient areas. There are no records of persistent and invasive non indigenous species in the Antarctic marine environment. So, why are we concerned about bioinvasion in maritime Antarctica?

We know now that Antarctica is not as isolated as once thought (Clarke et al., 2005). Non native organisms including terrestrial invertebrates and plants, marine Crustacean (adult and larvae) and algal dense mats of an introduced species (Enteromorpha intestinalis) have already been found in the Antarctic environment (Frenot et al., 2005). The rapid regional warming of the Antarctic Peninsula during the last 50 years also leads to more favorable conditions of establishment of non indigenous species (Convey, 2006).
Another factor that influences bioinvasion rates is the transport of people and goods that are increasing due to logistic, scientific, fisheries and tourism activities every year. Finally, non native species is the highest priority issue in the CEP (Committee on Environmental Protection) five year work plan highlighting that we need to be proactive.

Carlton (2009) listed 12 potential sources of errors that have led to invader underestimation. The lag time in recognizing that an introduced species has been mistakenly redescribed ranges from months to over 100 years. Although two hundred terrestrial plants and animals have been recognized as introduced in the sub Antarctic islands there are no records for the marine environment.

Considering these facts, the investigation of biogeographical patterns is an important tool for the identification of species origin. This study has investigated biogeographical patterns of benthic species recorded in Admiralty Bay. 


\section{Materials and Methods}

The study of species distribution focused on species of five target phyla (Mollusca, Echinodermata, Annelida, Artropoda and Chordata) found in Admiralty Bay and are available in a list at the site www.abbed.uni.lodz.pl, referring to the survey conducted by Sicinski et al. (2011). The study was made using the online database OBIS - Ocean Biogeography Information System (OBIS, 2012) and GBIF - Global Biodiversity Information Facility (GBIF, 2012). According to the distribution pattern in marine biogeographic zones proposed by Rass (1986), species were classified as: I) cosmopolitan: for those of wide distribution and that are present in at least three ocean basins; II) continuous: for species located in adjacent biogeographic areas (but at a lower rate than required for classification as cosmopolitan), III) disjoint: species that have occurrences in distinct biogeographic regions (separated by areas of non-occurrence); IV) endemic: for species distributed within the boundaries of the Southern Ocean (Sub Antarctica and Antarctica).

\section{Results}

The number of macrozoobenthos taxa of the phylum Annelida, Arthropoda, Mollusca, Echinodermata and Chordata recorded by Sicinski et al. (2011) was 603. In this study, we analyzed the distribution pattern of taxa identified at species level, totalling 529 species (87.7\%). The phylum Arthropoda showed the largest number of taxa (257), proving to be the one with the greatest biodiversity in the marine environment of Admiralty Bay from the phyla studied. The phylum Chordata registered the lowest number of taxa (16).

Most species of Admiralty Bay phyla studied are endemic to Sub Antarctica and Antarctica (Figure 1). The highest percentage of endemic species was found to the phylum Echinodermata. The second highest percentage was of species with continuous distribution. The phylum Chordata had the highest percentage of species with this distribution. Most cosmopolitan species were from the phyla Annelida. The percentage of disjoint species of Chordata and Annelida were the highest among the phyla studied. Some species were not found in databases, and the phylum Annelida presented the highest percentage of species with no data (Figure 1). Cosmopolitan (Table 1) and Disjoint (Table 2) species were classified according to their dominance pattern in Antarctica, Sub Antarctica, South America and other bioregions.

\section{Discussion}

The introduction of a species is not always documented. Species that were introduced many years ago (historical introductions) are already in complete equilibrium with the native biota (Villac et al., 2008). Cosmopolitan species are often classified as cryptogenic, species that cannot be recognized as native or introduced (Carlton, 2009). In NIS surveys cryptogenic species are often indicated as potential introduced species to avoid underestimation of bioinvasion under a precautionary approach.

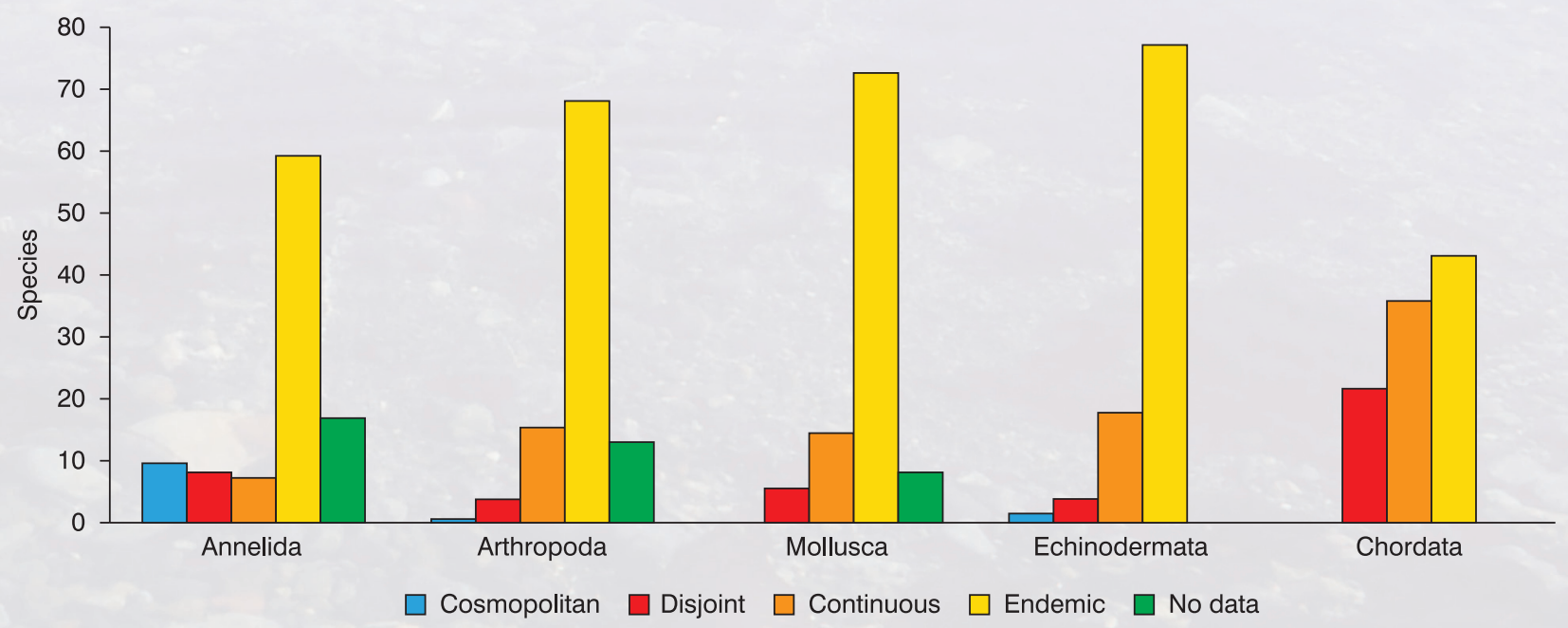

Figure 1. Distribution patterns of the 539 benthic species of Admiralty Bay of five target phyla (Mollusca, Echoinodermata, Annelida, Artropoda and Chordata).

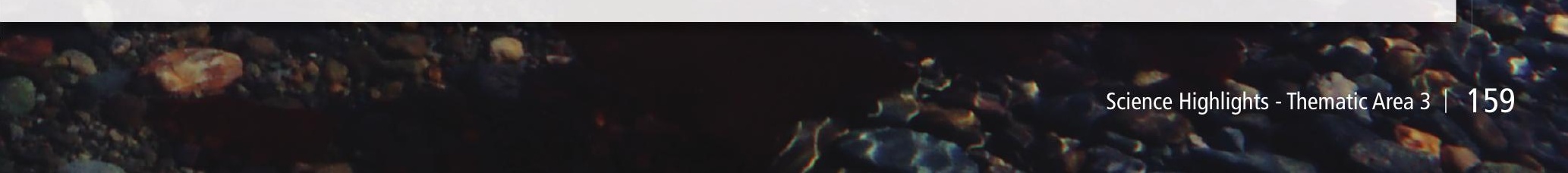


Table 1. Percentage of records in the Southern Ocean, South America and other bioregions of cosmopolitan species with their respective dominance pattern.

\begin{tabular}{|c|c|c|c|c|c|}
\hline \multicolumn{6}{|c|}{ I- Substantial number of records in Antarctic and Sub Antarctic } \\
\hline & Number of records & Antarctic & Sub Antarctic & South America & Others \\
\hline Hauchiella tribullata & 88 & 15.9 & 0 & 0 & 84.1 \\
\hline Leucothoe spinicarpa & 527 & 11.2 & 3.4 & 5.1 & 80.3 \\
\hline Molpadia musculus & 283 & 16.6 & 2.5 & 12.4 & 68.5 \\
\hline Neanthes kerguelensis & 271 & 18.8 & 5.5 & 2.2 & 73.5 \\
\hline \multicolumn{6}{|c|}{ II-Few records in Antarctic an Sub Antarctic in relation to total } \\
\hline & Number of records & Antarctic & Sub Antarctic & South America & Others \\
\hline Artacama proboscidea & 320 & 1.2 & 0 & 0 & 98.8 \\
\hline Brada villosa & 673 & 0.9 & 0 & 0 & 99.1 \\
\hline Capitella capitata & 6468 & 0.1 & 0 & 0.6 & 99.3 \\
\hline Levinsenia gracilis & 3684 & 0.3 & 0 & 0.5 & 99.2 \\
\hline Mystides borealis & 184 & 6.5 & 0 & 0 & 93.5 \\
\hline Notomastus latericeus & 5967 & 0.6 & 0.1 & 0.4 & 98.9 \\
\hline Ophelina cylindricaudata & 862 & 4.9 & 0 & 1.0 & 94.1 \\
\hline Pista cristata & 1773 & 0.4 & 0 & 0 & 99.6 \\
\hline Scalibregma inflatum & 4600 & 0.05 & 0.05 & 0.05 & 98.5 \\
\hline Syllis armillaris & 589 & 3.9 & 0 & 0.8 & 95.3 \\
\hline Thelepus cincinnatus & 827 & 6.2 & 0.4 & 0.1 & 93.3 \\
\hline
\end{tabular}

In the present study we investigated the species origin of 44 species that presented a disjoint or cosmopolitan pattern of distribution from their dominance pattern in Antarctica, Sub Antarctica, South America and other bioregions. The biogeographical patterns of species with few records cannot be well established. Cosmopolitan patterns appear to be correlated to taxonomic misidentification or to the occurrence of cryptic species. Particularly cosmopolitan patterns with few records in Antarctica and Sub Antarctica are probably a complex of species that are being revealed by molecular studies. Most disjoint species predominate in Antarctica and Sub Antarctica indicating their origin in the Southern Ocean. Only a few disjoint species, especially for the most number of records in South America, deserve further investigation.

\section{Conclusion}

The great majority of investigated species were endemic to the Southern Ocean. The second highest percentage was of species with continuous distribution. Disjoint and cosmopolitan species represented only $8.3 \%$ of the total. The results obtained do not allow us to make conclusions about which species were introduced to the Southern Ocean. However they provide detailed information about disjoint and cosmopolitan species indicating which species deserve further investigation.

\section{Acknowledgements}

This work integrates the National Institute of Science and Technology Antarctic Environmental Research (INCTAPA) that receives scientific and financial support from the National Council for Research and Development (CNPq process: $n^{\circ}$ 574018/2008-5) and Carlos Chagas Research Support Foundation of the State of Rio de Janeiro (FAPERJ $\left.\mathrm{n}^{\circ} \mathrm{E}-16 / 170.023 / 2008\right)$. The authors also acknowledge the support of the Brazilian Ministries of Science, Technology and Innovation (MCTI), of Environment (MMA) and InterMinistry Commission for Sea Resources (CIRM). 
Table 2. Percentage of records in the Southern Ocean, South America and other bioregions of disjoint species with their respective dominance pattern.

I- Dominance in Antarctic and Sub Antarctic

\begin{tabular}{|c|c|c|c|c|c|}
\hline & Number of records & Antarctic & Sub Antarctic & South America & Others \\
\hline Cirrophorus brevicirratus & 21 & 81.0 & 0 & 0 & 19.0 \\
\hline Hippomedon kergueleni & 46 & 74.0 & 21.7 & 0 & 4.3 \\
\hline lathrippa sarsi & 18 & 66.7 & 27.8 & 0 & 5.5 \\
\hline Laetmonice producta & 199 & 66.3 & 9.1 & 1.5 & 23.1 \\
\hline Mirandotanais vorax & 37 & 70.3 & 10.8 & 0 & 18.9 \\
\hline Neobuccinum eatoni & 190 & 91.0 & 8.4 & 0 & 0.6 \\
\hline Ophiolimna antarctica & 120 & 61.7 & 16.2 & 1.7 & 20.0 \\
\hline Ophioplocus incipiens & 202 & 54.5 & 44.0 & 0.5 & 1.0 \\
\hline Praxillella kerguelensis & 7 & 85.7 & 0 & 0 & 14.3 \\
\hline Syllides articulosus & 42 & 92.9 & 0 & 0 & 7.1 \\
\hline Synoicum adareanum & 173 & 96.5 & 0 & 0.6 & 2.9 \\
\hline Tanaopsis gallardoi & 9 & 88.9 & 0 & 0 & 11.1 \\
\hline
\end{tabular}

II- Dominance in Antarctic. Sub Antarctic and South America Number of records Antarctic Sub Antarctic

South America

Others

\begin{tabular}{|c|c|c|c|c|c|}
\hline Amphiura joubini & 245 & 49.4 & 3.7 & 46.5 & 0.4 \\
\hline Cnemidocarpa verrucosa & 257 & 82.9 & 10.5 & 5.8 & 0.8 \\
\hline Laevilitorina caliginosa & 66 & 16.7 & 34.8 & 42.4 & 6.1 \\
\hline Laonice weddellia & 92 & 81.5 & 15.2 & 3.3 & 0 \\
\hline Lissarca miliaris & 52 & 25.0 & 9.6 & 63.5 & 1.9 \\
\hline Polycheria antactica & 63 & 35.0 & 25.4 & 19.0 & 20.6 \\
\hline Travisia kerguelensis & 66 & 59.1 & 9.1 & 21.2 & 10.6 \\
\hline Yoldia eightsi & 132 & 78.1 & 11.4 & 8.9 & 1.6 \\
\hline \multicolumn{6}{|c|}{ II- Dominance in Antarctic and South America } \\
\hline & Number of records & Antarctic & Sub Antarctic & South America & Others \\
\hline Astyra antarctica & 5 & 80.0 & 0 & 20.0 & 0 \\
\hline Brania rhopalophora & 28 & 50.0 & 0 & 3.6 & 46.4 \\
\hline Corella eumyota & 187 & 65.8 & 0.5 & 8.6 & 25.1 \\
\hline Lumbrineris magalhaensis & 137 & 48.9 & 0.7 & 18.2 & 32.2 \\
\hline Natatolana meridionalis & 28 & 78.6 & 0 & 21.4 & 0 \\
\hline Pista corrientis & 13 & 76.9 & 0 & 23.1 & 0 \\
\hline Pseudharpinia dentata & 61 & 63.9 & 0 & 34.4 & 1.7 \\
\hline Scoloplos marginatus & 82 & 90.2 & 0 & 7.3 & 2.5 \\
\hline Trypanosyllis gigantea & 24 & 66.7 & 0 & 12.5 & 20.8 \\
\hline
\end{tabular}




\section{References}

Carlton, J.T. (2009). Deep invasion ecology and the assembly of communities in historical time. In: Rilov, G. \& Crooks, J. Biological Invasions in marine ecosystems: Ecological, management and geographic perspectives. Heidelberg: Springer. Ecological Studies 204. $641 \mathrm{p}$.

Clarke, A.; Barnes, D.K.A. \& Hodgson, D.A. (2005). How isolated is Antartica? Trends in Ecology and Evolution, 20(1): 1-3.

Convey, P. (2006). Non-native species in the Antarctic terrestrial environment - presence, sources, impacts and predictions. In: De Poorter, M.; Gilbert, N.; Storey, B. \& Rogan-Finnemore, M. (Orgs.). Non-native species in the Antarctic - Final Report. New Zealand: University of Canterbury Christchurch. $40 \mathrm{p}$

Frenot, Y.; Chown, L.S.; Whinam, J.; Selkirk, P.M.; Convey, P.; Skotnicki, M. \& Bergstrom, D.M. (2005). Biological invasions in the Antarctic: extent, impacts and implications. Biological Reviews, 80: 45-72.

Global Biodiversity Information Facility - GBIF. (2012). Available from: < www.gbif.org > . (accessed: April 29, 2012).

Ocean Biogeography Information System - OBIS (2012). Available from: < www.iobis.org/mapper>. (accessed: April 29, 2012).

Rass, T. S. (1986). Vicariance ichtyogeography of Atlantic Ocean pelagial. Pelagic Biogeography, (49): 237-241.

Sicinski, J.; Jazdzewski, K.; De Broyer, C.; Presler, P.; Ligowski, R.; Nonato, E.F.; Corbisier, T.N.; Petti, M.A.V.; Brito, T.A.S.; Lavrado, H.P.; Błazewicz-Paszkowycz, M.; Pabis, K.; Jazdzewska, A. \& Campos, L.S. (2011). Admiralty Bay Benthos Diversity - A census of a complex polar ecosystem. Deep-Sea Research II, 58: 30-48

Villac, M.C.; Ferreira, C.E.L \& Junqueira, A.O.R. (2008). Bioinvasão. In: Baptista Neto, J.A.; Wallner-Kersanach, M. \& Patchineelam, S.M. Poluição marinha. Rio de Janeiro: Interciência. 412 p. 